\title{
The Red Flags of Tax Reporting on the Market Value
}

\author{
Nik Mohd Norfadzilah Nik Mohd Rashid ${ }^{1}$, Rohaya Md Noor ${ }^{2}$, Norazam Matsuski ${ }^{2}$, Barjoyai Bardai ${ }^{3}$, Jamalludin \\ Helmi Hashim ${ }^{1} \&$ Mohd Hafiz Harun ${ }^{1}$ \\ ${ }^{1}$ University Sultan Zainal Abidin, Malaysia \\ ${ }^{2}$ University Technology MARA, Malaysia \\ ${ }^{3}$ University Tun Abdul Razak, Malaysia \\ Correspondence: Nik Mohd Norfadzilah Nik Mohd Rashid, University Sultan Zainal Abidin, Malaysia. Tel: \\ 014-507-1610. E-mail: nikmfadzilah@unisza.edu.my
}

Received: December 21, 2013

Accepted: February 7, 2014

Online Published: March 26, 2014

doi: 10.5539/ibr.v7n4p142

URL: http://dx.doi.org/10.5539/ibr.v7n4p142

\begin{abstract}
The aim of this paper is to provide empirical evidence of the red flags in the level of tax reporting among the Shariah Compliance companies in Bursa Malaysia. The convenience sampling method was employed among 123 Shariah compliance companies of Bursa Malaysia. Meanwhile, the investigation period in this study had covered twelve years of continuous data, starting from the year 2001 until the year 2012. This study adopted the Current Based Model to calculate the level of Effective Tax Rate (ETR) as an independent variable while the firm values as dependent variable. It was revealed that due to the Creative Accounting strategies, there is a possibility of tax fraud occurring during the calculation of taxation level. These activities, which were applied in implementing tax planning mechanisms is however allowed by the GAAP under MFRS. As is commonly known, the purpose of tax reporting is to safeguard the interest of potential shareholders; however, these practices of aggressive tax planning strategies will result in differing perceptions from tax payers' and potential shareholders' perspectives. Therefore, aggressive tax planning strategies could be a red flag to financial fraud activities. Thus, this study would disclose some evidence on how financial fraud could be revealed from tax reporting strategies.
\end{abstract}

Keyword: tax planning, Effective Tax Rate (ETR), tax fraud, financial fraud, GAAP

\section{Introduction}

This study will examine the red flags of the tax reporting on the firm values of Shariah compliant companies on Bursa Malaysia from the year 2001 to 2012. As the number of Shariah capital market players keep on increasing, it is common for potential investors not to rely on the presence of Shariah counter only, but they also concern about the quality of financial reporting which relates to the tax reporting strategies of the companies in order to maximize their investments' profits.

In relation to the aggressiveness of tax reporting activities, it is believed to have some effect on the quality of financial information provided by the companies. However, it is worth noting that most of the companies in Malaysia are using these kinds of strategies as it is allowed under the General Acceptable Accounting Practice (GAAP). Therefore this study will give some useful input to policymakers by providing empirical evidence of the effect of tax reporting strategies on the firm values of the Shariah compliant companies that are listed on Bursa Malaysia. In addition, it is important to note that the tax reporting level will be the proxy by the effective tax rate level (Noor, Fadzillah, \& Mastuki, 2010).

\section{Issues of the Study}

Every potential investor is usually concern with the reliability of financial information disclosed in a company's financial reports. This is because the financial reports are based on the estimates of calculations provided by the listed companies (Hashim, 2012). These estimations include the tax reporting information which can be said to influence the investment decision among the potential investors (McNichols \& Stubben, 2008).

Moreover, the potential investors usually face difficulties in assessing the level of risk they have to bear from the investments made. They thus demand for a better quality financial reporting (Givoly, Hayn, \& Katz, 2010) because the aggressiveness of tax reporting activities will reduce the quality of financial information that is disclosed to the potential shareholders, (Mohd Radzi, Islam, \& Ibrahim, 2011). In other words, these creative 
accounting strategies should be employed without increasing the possibilities of financial losses for the investors.

A similar research on tax reporting issues was done by (Kassem, 2012), who reported that there is a significant association between tax reporting and the investors' decision. He also argued that high levels of aggressive tax reporting could lead to accounting manipulation. Thus, if the potential investors rely on these types of reporting, the risk of financial losses among potential investors will be higher (Zulfiqar, Shah, Butt, \& Tariq, 2011). Furthermore, the aggressiveness of tax reporting activities will also create uncertain outcomes for the potential investor because these kinds of activities are usually used to dress up a company's financial position and will not guarantee their future profits (Liang, Wang, \& Farquhar, 2009). Therefore by considering the previous research on tax reporting issues, the aim of this particular study is to investigate the possible impact of tax reporting on the market value of Shariah compliant companies on Bursa Malaysia.

\section{Prior Research}

\subsection{Tax Reporting}

The tax reporting is generally governed by the domestic legislations of a particular country. In Malaysia, the corporate tax is administered by the Inland Revenue Board of Malaysia (IRBM). The corporate tax contributes the most to the tax revenue that is about $45 \%$ of Malaysia's total income tax revenue.

A good tax system should be designed to comply with the following principles: revenue, fair and equity, neutral, growth, certainty, transparency, convenient, simple, economy of collection and minimum tax gap (AICPA). However, some of these principles are in conflict with each other, such as the principles of revenue, fair, neutral and growth.

For example, the provision of tax incentives to selected economic sectors with the objective of promoting the economic growth has resulted in loss of revenue and further caused inequity and non-neutrality in the tax system. Tax scholars believe that inequity and non-neutrality in the tax system will contribute to tax avoidance and result in an increase of compliant costs for tax audits and investigations.

The tax returns form $\mathrm{C}$ submitted to the tax authorities which contain details of the adjustment of tax computation is treated as confidential data. However, FRS 112 requires the following disclosures of tax information in the companies' financial statements: a) Income taxes; b) Deferred tax assets/liabilities; c) Reconciliation of tax expense and deferred tax; d) Financial performance statement; e) Financial Performance Statement and f) Notes to the accounts.

Another issue to be considered in taxation is the provision for deferred taxation which accounts for temporary differences of transactions between financial reporting and tax reporting. For example, the treatment of depreciation and capital allowance, exempt income and other tax incentives. In addition, the different rules between tax reporting and financial reporting have also caused the permanent differences (Sodan, 2012). Hence, it can be said that taxpayers' strategies and the dual reporting in their tax reporting have contributed to the gap between incomes reported to capital market and tax authorities. Thus, the reconciliation information and corporate effective tax rate reported in the notes to the accounts is value relevant in determining the quality of the reported earnings.

The tax system is a mechanism to achieve a country's economic goals. However, the trend of fiscal deficit reported in part reflects the inefficiency and ineffectiveness of the conventional tax system. The growth in tax revenue whether from income taxes (corporate, personal and body of person) or indirect taxes (sales tax, service tax, import and export duties) does not commensurate with the increase in the number of business formations, population and consumer spending. 


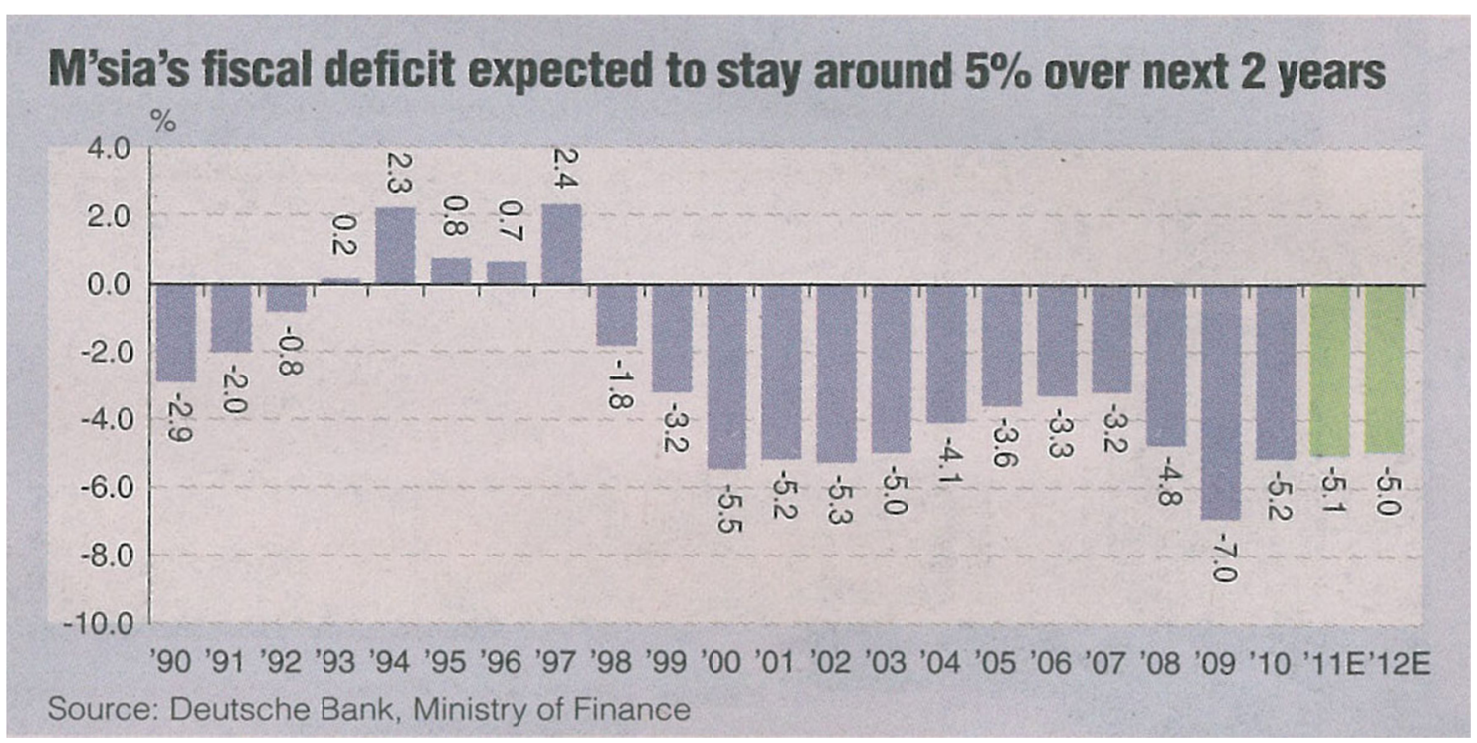

Figure 1. Trend of fiscal deficit

Source: The Edge 20 June 2011.

\subsection{Effective Tax Rates}

An effective tax rate can be defined as the actual amount of tax paid by the companies (Noor et al., 2010). This means that even though business organizations are imposed with tough tax provision under Income Tax Act 1967, not all of them will make payment in accordance with the statutory tax rate (STR). This is because most companies will utilize tax reporting for their business income in order to pay the lowest tax possible. At the same time, tax reporting is the legitimate way for business organizations to make tax reporting for their businesses. They can conduct tax reporting by utilizing the tax incentives that have been provided under Income Tax Act 1967.

\subsection{Theory of Tax Reporting}

Tax reporting has been discussed rigorously by previous research. Most of the area of study were concerned with the ability of the tax payers to minimize their tax burden or focused on the developing of new tax policies for some countries. In addition, this theory had also been widely discussed in terms of investigations on tax assessment system especially for public listed companies in Malaysia (Noor et al., 2010). Meanwhile, the earliest literature regarding the tax reporting theory was conducted by (Joseph, 1962), where he indicated that the tax reporting is the capacity of the tax payer in terms of managing their income either in business activities or for personal income in order to minimize their tax burden in legitimate ways.

Figure 2 below provides empirical evidence of the variations of tax paid by companies listed on Bursa Malaysia from 1993 to 2006. The variations of tax paid indicate inefficiency in the conventional tax system whereby the equity and neutrality tax principles have been distorted. The gap between the statutory tax rate and effective tax rates during the official assessment tax regime and self assessment tax regime is wider, that is from $5.5 \%$ to $6.9 \%$.

Therefore Figure 2 above provides empirical evidence on the variations of tax paid by companies listed on Bursa Malaysia from the period of 1993 to 2006 (Noor et al., 2010). The variations in the effective tax rates paid (actual tax burdens paid by companies) indicate that the equity and the neutrality principles of the conventional tax system have been distorted. Based on the figures above, most of the listed companies that were analysed in the study are aggressively utilising tax reporting in order to pay the lowest amount possible for their tax burden because the tax regulation has permitted such tax reporting activities.

In addition, the previous study for effective tax rate provides the statistics of the effective tax rates paid by companies and the corresponding official or statutory tax rates used during the official assessment tax regime and self assessment tax regime (Rohaya et al., 2010). The gap between the statutory tax rate (official tax rate) and effective tax rates during the official assessment tax regime and self assessment tax regime has widened from $5.5 \%$ to $6.9 \%$. This evidence indicates the declining trend of tax paid by these companies. 


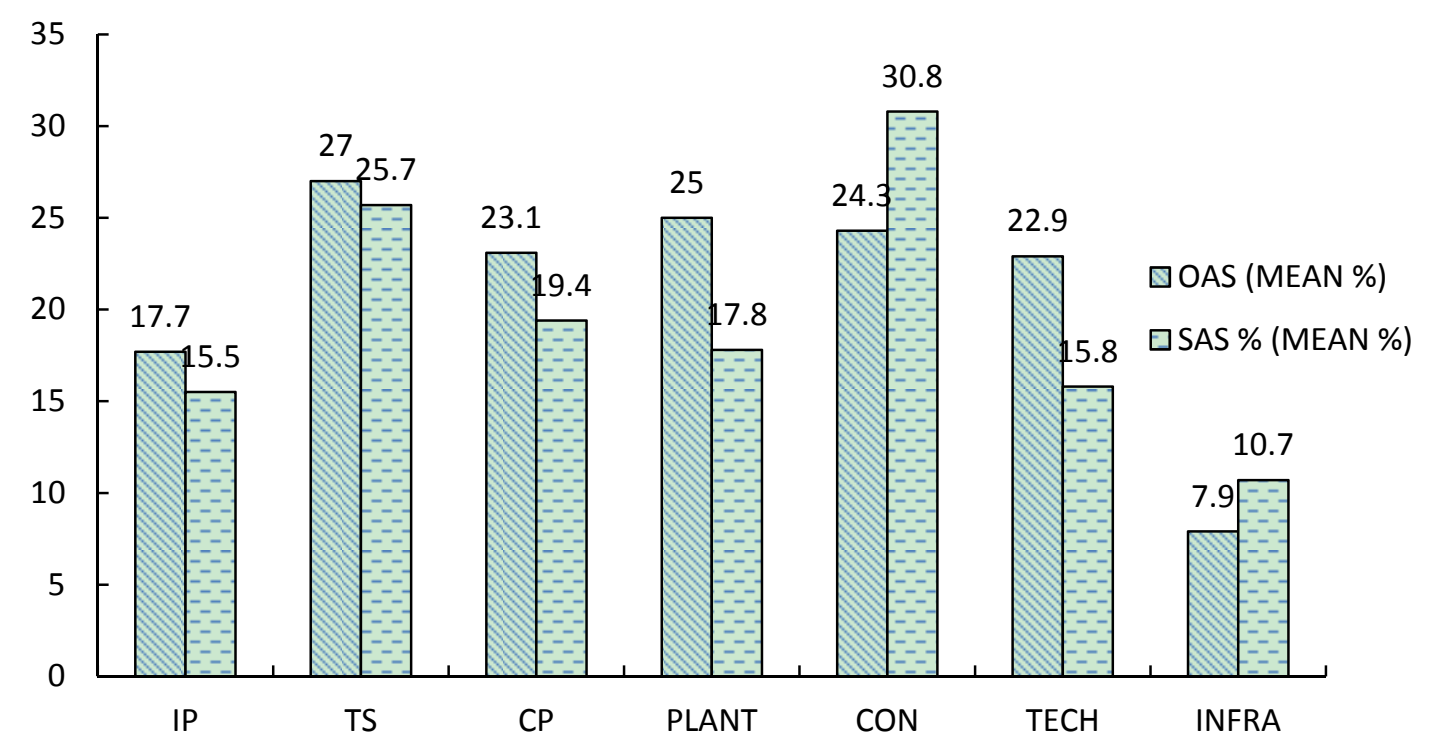

Figure 2. Descriptive statistics for Statutory Tax Rate (STR) and current-based ETR

Source: Rohaya et al., 2010.

Therefore, the possible reason for such a gap between statutory tax rate and effective tax rate among business tax payers is the possibility that there are criminal fraud activities occurring in the business organizations (DeZoort, Harrison, \& Schnee, 2012). The criminal fraud activity can be related to the existing gap because it is common knowledge that tax payers will try to reduce their tax burden when they feel the statutory tax rate is too high to bear. In order to minimize their tax burden, they may engage in some kind of financial fraud activity in order to ensure their tax burden can be reduced as low as possible. There are many ways to conduct fraud on tax burdens, among them by making false recordings and also with creative accounting activities. Furthermore, these gaps also exist because there is opportunity for such companies to commit fraud in their business activities (Thornton, 2012). Such an opportunity means that some tax payers would probably claim double deductions in a false manner.

\subsection{Tax Reporting Relationships with Firm Value of Company}

Tax reporting will usually discuss the amount of tax burden the business organizations are able to minimize for the tax authorities. In other words, potential shareholders will consider this capability as a competitive advantage to other listed companies in the capital market. A related study by (Lo, Wong, \& Firth, 2010) discovered that the income tax expenses were significantly associated with the income shifting among listed companies in China. This study also revealed that the potential investors were a little concerned on how tax management will be managed by the particular companies. In other words, the tax reporting style of listed companies in China can give them an edge over their competitors.

Another research that examined how tax reporting impacted firm values was conducted by (Wang, 2010). In his study, Wang claimed that the tax reporting strategies would help the business organizations in maximizing their corporate income. This scenario will influence the potential investors to be more attracted to the tax reporting strategies. However, it is important to be reminded that if the tax reporting is applied aggressively, it may cause a decrease in the firm values of a company. On the other hand, there is also a study conducted by Beisland (2009) who claimed there was insignificant association of tax reporting strategies with the value relevance of the company. In Beisland's research, it was argued that not all the potential investors will be concerned with the tax reporting strategies made by the company. In most cases, the share price level in the capital market will be negatively affected the more governance carried out by the company in terms of tax reporting strategies.

\section{Research Objective and Research Question}

The goal of this study is to examine the possible impacts of tax reporting strategies on the firm values in conjunction with the growing numbers of potential stakeholders in the Shariah compliant capital market in Malaysia. Therefore, the specific research objective is as follows: 
RO1:To investigate the possible impacts of tax reporting level on the market values of Shariah compliant companies listed on Bursa Malaysia.

In order to achieve the above mentioned purpose of this study, a research question was developed to guide this research to accomplish its current research objectives. Therefore, the research question below relates to the research objectives as mentioned above. Therefore, the specific research question for this study is as follows:

RQ1: Can the tax reporting level be considered as a red flag towards the influence of market values among Shariah compliant companies listed on Bursa Malaysia?

\section{Research Methodology}

This study employed the convenience of the sampling technique on all the Shariah compliant companies which were listed on Bursa Malaysia from 2001 until 2012. In other words, only those companies which had been listed every year from the year 2001 until 2012were selected as the sample of the study. Meanwhile, any companies with missing financial data in their annual reports during the investigation period were eliminated. Therefore, the final sample gathered for this purpose of study is 123 companies. In order to investigate the red flag from tax reporting strategies, the descriptive analysis have been employed in order to trace any unusual level (red flag) of effective tax rate during the investigation period.

This was followed with the association's analyses between the effective tax rate levels towards the market value, they were recorded as ETR_NR and ETR_R. The ETR_NR refers to the actual level of the effective tax rate during the investigation period. Meanwhile, the ETR_R refers to the effective tax rate with not more than $100 \%$ level. This step was to identify the significant level towards the market value in this study. All of the analyses mentioned were tested with the E-Views statistical software.

\section{Data Analysis}

Table 1. Descriptive statistic of ETR 2001-2012

\begin{tabular}{lcc}
\hline & ETR_R_2001-2012 & STR_2001-2012 \\
\hline Mean & 0.112141 & 0.257665 \\
Median & 0.109188 & 0.260000 \\
Maximum & 0.249834 & 0.270000 \\
Minimum & 0.000110 & 0.250000 \\
Std. Dev. & 0.076217 & 0.008371 \\
Skewness & 0.171918 & 0.460218 \\
Kurtosis & 1.758231 & 1.581247 \\
Probability & 0.000000 & 0.000000 \\
Observations & 1476 & 1476 \\
\hline
\end{tabular}

Table 1 above shows the descriptive analysis between the effective tax rate levels when compared to the statutory tax rate levels. Hence, the result shows the average level for effective tax rate from the year 2001 until 2012 is around 0.112141 or $11 \%$. This figure is moderately lower for tax planning strategies employed for these twelve years consecutively as compared to the statutory tax rate level during that period. However, this scenario also has a significant impact on the market value. Hence, this study also shows that the minimum level of effective tax rate during the investigation period is 0.000110 or $0.01 \%$. Based on the tax reporting pattern this figure can be considered as a red flag as it results in a significant impact on the market value.

Thus, this pattern is important for shareholders' interest, enabling them to verify whether the companies they have selected are worth investing in due to the possibility of such companies employing accounting manipulation under the tax planning strategies. The aggressive on tax planning strategies is closely related to this situation because on average the selected companies only reported the tax expenses around $11 \%$ as compared to $25 \%$ for the statutory tax rate. Therefore, this could be a red flag from tax planning strategies among of selected companies. 
Tabel 2. Tax reporting relationship towards the market value

\begin{tabular}{|c|c|c|c|c|}
\hline Variable & Coefficient & Std. Error & t-Statistic & Prob. \\
\hline _2001_ETR_NR & -184.7262 & 215.2110 & -0.858349 & 0.3926 \\
\hline _2002_ETR_NR & -258.2437 & 227.3025 & -1.136124 & 0.2584 \\
\hline _2003_ETR_NR & 93.52151 & 207.8111 & 0.450031 & 0.6536 \\
\hline _2004_ETR_NR & 515.1990 & 237.9769 & 2.164911 & 0.0326 \\
\hline _2005_ETR_NR & 56.12051 & 200.5576 & 0.279822 & 0.7801 \\
\hline _2006_ETR_NR & -556.9400 & 224.1833 & -2.484306 & 0.0145 \\
\hline _2007_ETR_NR & 258.5362 & 207.2944 & 1.247194 & 0.2150 \\
\hline _2008_ETR_NR & 133.6027 & 176.5458 & 0.756760 & 0.4508 \\
\hline _2009_ETR_NR & -316.1055 & 200.9598 & -1.572979 & 0.1186 \\
\hline _2010_ETR_NR & 813.9790 & 250.6022 & 3.248092 & 0.0015 \\
\hline _2011_ETR_NR & -390.1210 & 264.9338 & -1.472523 & 0.1437 \\
\hline _2012_ETR_NR & -148.9894 & 180.9632 & -0.823313 & 0.4121 \\
\hline $\mathrm{C}$ & 255.1732 & 79.71452 & 3.201088 & 0.0018 \\
\hline R-squared & 0.258238 & Mean dependent var & 268.0785 & \\
\hline Adjusted R-squared & 0.177319 & S.D. dependent var & 510.9993 & \\
\hline S.E. of regression & 463.4854 & Akaike info criterion & 15.21510 & \\
\hline Sum squared resid & 23630056 & Schwarz criterion & 15.51233 & \\
\hline Log likelihood & -922.7289 & Hannan-Quinn criter. & 15.33584 & \\
\hline F-statistic & 3.191302 & Durbin-Watson stat & 1.787822 & \\
\hline Prob(F-statistic) & 0.000605 & & & \\
\hline
\end{tabular}

Based on Table 2 above, it shows that there is a significant relationship between the tax reporting level and the market value of the 123 Shariah compliant companies on Bursa Malaysia. This is clearly indicated by the P-value of 0.000605. This association supports the assumption of this study where the higher the effective tax rate reported by the companies, the higher the effect on the market value. In other words, the market value of companies will be affected with the higher level of effective tax rate applied by the companies. At the same time, this situation can also be considered as a red flag due to the fact that an aggressive pattern of tax reporting will have a significant impact on the market value. Hence, the level of tax reporting can also be easily manipulated by the tax payers in order to give more attractions on the market value itself. Therefore, by having a significant association on the effective tax rate level of the market value, this could lead to shareholders having a different perception of the companies.

This is because such an association can be manipulated under tax planning strategies in order to show potential shareholders that the companies are able to pay more income tax expenses when provided with a higher income level. Therefore, the potential shareholders will not be aware how the companies are able to manipulate the tax reporting under tax planning strategies in order to have a better impact on the market value of the companies.

Table 3 shows the associated results with a restricted effective tax rate level on the market value of selected companies. The purpose for such a restriction on the level of effective tax rate is because there were some selected companies who declared more than $100 \%$ of tax rates. Therefore, in this section those companies who had declared more than $100 \%$ of tax rate were however limited to only $100 \%$ tax rate. This step is vital for this study in order to show the possible impact if the companies did not employ aggressive tax planning strategies. Therefore, such a step will reflect how the red flag on tax reporting level can be manipulated under tax planning strategies towards the market value. 
Table 3. Restricted tax reporting level towards the market value

\begin{tabular}{|c|c|c|c|c|}
\hline Variable & Coefficient & Std. Error & t-Statistic & Prob. \\
\hline _2001ETR_R & -234.8475 & 107.8463 & -2.177612 & 0.0316 \\
\hline _2002ETR_R & 46.97334 & 114.7502 & 0.409353 & 0.6831 \\
\hline _2003ETR_R & -38.64979 & 92.30458 & -0.418720 & 0.6762 \\
\hline _2004ETR_R & 93.52026 & 51.68345 & 1.809482 & 0.0731 \\
\hline _2005ETR_R & 10.40871 & 58.46428 & 0.178035 & 0.8590 \\
\hline _2006ETR_R & -65.71130 & 95.96400 & -0.684750 & 0.4949 \\
\hline _2007ETR_R & 18.13466 & 61.92031 & 0.292871 & 0.7702 \\
\hline _2008ETR_R & 37.65851 & 56.63955 & 0.664880 & 0.5075 \\
\hline _2009ETR_R & -121.8030 & 86.41542 & -1.409505 & 0.1615 \\
\hline _2010ETR_R & 547.0965 & 116.6029 & 4.691962 & 0.0000 \\
\hline _2011ETR_R & -364.2335 & 99.62239 & -3.656142 & 0.0004 \\
\hline _2012ETR_R & 2.870934 & 14.33493 & 0.200275 & 0.8416 \\
\hline $\mathrm{C}$ & 278.3517 & 67.14006 & 4.145836 & 0.0001 \\
\hline R-squared & 0.192099 & \multicolumn{2}{|c|}{ Mean dependent var } & 268.0785 \\
\hline Adjusted R-squared & 0.103964 & \multicolumn{2}{|c|}{ S.D. dependent var } & 510.9993 \\
\hline S.E. of regression & 483.7076 & \multicolumn{2}{|c|}{ Akaike info criterion } & 15.30052 \\
\hline Sum squared resid & 25737034 & \multicolumn{2}{|c|}{ Schwarz criterion } & 15.59774 \\
\hline Log likelihood & -927.9818 & \multicolumn{2}{|c|}{ Hannan-Quinn criter. } & 15.42125 \\
\hline F-statistic & 2.179610 & \multicolumn{2}{|c|}{ Durbin-Watson stat } & 1.884610 \\
\hline Prob(F-statistic) & 0.017370 & & & \\
\hline
\end{tabular}

Thus, the figures in Table 3 above show how the restrictions on the tax reporting level has reduced the impact to the market value. Furthermore, the P-value for Table 3 is 0.01737 , which proves the above assumption to be true as it is less significant as compared to the P-value in Table 2 which is 0.000605 . The difference in the significant levels between Table 2 and Table 3 indicates that there is a different impact on the market value of companies. In other words, if the companies employed an aggressive tax reporting level which is more than $100 \%$ tax rate level; this will result in a more significant impact on the market value. However, if the companies employed lower tax planning strategies, it will have a lesser impact on the market value.

Therefore, the scenario in Table 2 could be beneficial to the tax payers by having a positive impact on the market value, while the scenario in Table 3 could be beneficial to the shareholders because it will give a real impact on the market value but with unaggressive tax planning strategies by the tax payers.

\section{Discussions on the Findings}

The following section will discuss the findings from the previous sections. It is important to be bear in mind that the purpose of this study is "to investigate the possible impacts of tax reporting level on the market values of Shariah compliant companies listed on Bursa Malaysia". Therefore, based on the results from Table 2 and Table 3 in the previous section, they indicate that there is a significant association with tax reporting level on the market value of selected companies on Bursa Malaysia. These two tables represent the impact patterns with the actual effective tax rates level (recorded as ETR_NR) towards the market value and also represent the restricted effective tax rate (recorded as ETR_R). The purpose of recoding the effective tax rate level is to investigate the impact changes on the market value.

With reference to Table 4 below, a result of 0.000605 shows that practicing aggressive tax planning strategies will have a significant impact on the market value. However, if companies did not employ aggressive tax planning strategies, this will reduce the significant level towards the market value. These results are illustrated in Table 4 below: 
Table 4. Findings of the study

\begin{tabular}{lll}
\hline Descriptions & ETR level condition & P-Value @ significant level towards market value \\
\hline The actual level of ETR & $>100 \%$ & 0.000605 \\
The recoded level of ETR & $\leq 100 \%$ & 0.017370 \\
\hline
\end{tabular}

Furthermore, in order to answer the research question proposed in this study, descriptive analysis was utilized in order to trace any unusual level of effective tax rate during the investigation period. Therefore, based on Table 1, the result indicates that there is a red flag of tax reporting pattern during the investigation period. As was previously reiterated, the average level of effective tax rate for twelve consecutive years is around $11.2 \%$ as compared to $25 \%$ of statutory tax rate. This figure has probably been manipulated by the tax payers under tax planning strategies in order to show their capabilities in paying tax from their business activities. However, this pattern does not guarantee shareholders' profits because the higher level of income tax expenses could consist of deferred tax declared by the companies.

\section{Conclusion}

Based on the discussions above, this study has provided empirical evidence on the associations between the taxes reporting level towards the firm value. Hence, the study indicates that the tax reporting level can influence the market value in the capital market. At the same time, the red flag could also be identified from such accounting strategies in order to show to the potential shareholders the possibility of accounting manipulation under tax planning strategies. As reported in the section of analyses in this study, there is a significant difference between the levels of effective tax rate with the statutory tax rate.

These situations also were contributed to the significant association of aggressive tax reporting level to the market value in the capital market. However, this study only provided empirical evidence on the possibility of accounting manipulation from red flags of tax reporting strategies among of Shariah compliance companies on Bursa Malaysia. In addition, this study also recommends the need for future research on tax planning with earnings management level and its impact on other firm values.

\section{References}

Beisland, L. A. (2009). A Review of the Value Relevance Literature. The Open Business Journal, 2(1), 7-27. http://dx.doi.org/10.2174/1874915100902010007

DeZoort, F. T., Harrison, P. D., \& Schnee, E. J. (2012). Tax Professionals' Responsibility for Fraud Detection: The Effects of Engagement Type and Audit Status. Accounting Horizons, 26(2), 289-306. http://dx.doi.org/10.2308/acch-50137

Givoly, D., Hayn, C. K., \& Katz, S. P. (2010). Does Public Ownership of Equity Improve Earnings Quality? The Accounting Review, 85(1), 195-225. http://dx.doi.org/10.2308/accr.2010.85.1.195

Hashim, H. A. (2012). The Influence of Culture on Financial Reporting Quality in Malaysia. Asian Social Science, 8(13), 192-200. http://dx.doi.org/10.5539/ass.v8n13p192

Joseph, A. M. (1962, July). Basic principles and features of business tax planning. New York Certified Public Accountant (pre-1986), 32(7), 460.

Kassem, R. (2012). Earnings Management and Financial Reporting Fraud: Can External Auditors Spot the Difference ? American Journal of Business and Management, 1(1), 30-33.

Liang, C. J., Wang, W. H., \& Farquhar, J. D. (2009). The influence of customer perceptions on financial performance in financial services. International Journal of Bank Marketing, 27(2), 129-149. http://dx.doi.org/10.1108/02652320910935616

Lo, A. W. Y., Wong, R. M. K., \& Firth, M. (2010). Tax, Financial Reporting, and Tunneling Incentives for Income Shifting: An Empirical Analysis of the Transfer Pricing Behavior of Chinese-Listed Companies. The Journal of the American Taxation Association, 32(2), 1-26. http://dx.doi.org/10.2308/jata.2010.32.2.1

McNichols, M. F., \& Stubben, S. R. (2008). Does Earnings Management Affect Firms' Investment Decisions? The Accounting Review, 83(6), 1571-1603. http://dx.doi.org/10.2308/accr.2008.83.6.1571

Mohd Radzi, S. N. J., Islam, M. A., \& Ibrahim, S. (2011). Earning Quality in Public Listed Companies: A Study on Malaysia Exchange for Securities Dealing and Automated Quotation. International Journal of Economics and Finance, 3(2), 233-245. http://dx.doi.org/10.5539/ijef.v3n2p233 
Noor, R., Fadzillah, N. S. M., \& Mastuki, N. A. (2010). Corporate Tax Planning : A Study On Corporate Effective Tax Rates of Malaysian Listed Companies. International Journal of Trade, Economics and Finance, 1(2), 189-193. http://dx.doi.org/10.7763/IJTEF.2010.V1.34

Sodan, S. (2012). Book-Tax Differences and Companies' Financial Characteristics: The Case of Croatia. The Business Review, 19(2), 265-272.

Thornton, J. M. (2012). The Fraud Triangle: Fraudulent Executives, Complicit Auditors and Intolerable Public Injury (pp. 352-357). Mill Valley, CA: Snowball Narrative.

Wang, X. T. (2010). Tax Avoidance, Corporate Transparency, and Firm Value Texas. Retrieved from http://ssrn.com/abstract=1904046

Zulfiqar, S., Shah, A., Butt, S., \& Tariq, Y. B. (2011). Use or Abuse of Creative Accounting Techniques. International Journal of Trade, Economics and Finance, 2(6), 531-536.

\section{Copyrights}

Copyright for this article is retained by the author(s), with first publication rights granted to the journal.

This is an open-access article distributed under the terms and conditions of the Creative Commons Attribution license (http://creativecommons.org/licenses/by/3.0/). 